\title{
The intermittent drying of wheat by microwave and fluidized bed drying
}

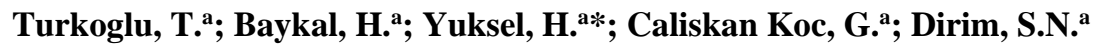

${ }^{a}$ Department of Food Engineering, University of Ege, Izmir, Turkey.

*E-mail of the corresponding author: hirayuksel@gmail.com

\begin{abstract}
The objective of the study is to investigate the effects of different drying processes (convective hot air, microwave, and fluidized bed drying) and combined drying methods on the drying characteristics and physical properties of the dried wheat and the power consumption of the dryers. The lowest moisture content and water activity values were observed for the $25 \mathrm{~min}$ of drying in fluidized bed dryer $\left(60^{\circ} \mathrm{C}\right)$ and following $16 \mathrm{~min}$ in microwave dryer (540W). The lowest power consumption was observed in the $60^{\circ} \mathrm{C}-180 \mathrm{~W}$ fluidized bed-microwave combination $(0.77 \mathrm{kWh})$ compared to the other combined trials.
\end{abstract}

Keywords: wheat; convective drying; microwave drying; fluidized bed drying intermittent drying. 


\section{Introduction}

The ready to us products that are precooked and dried are called as "parboiled"[1]. The main objective of parboiling on wheat is a versatile that can be used in bread, salads, casseroles, stew, desserts, and served as side dish.

Drying is applied to decrease the moisture content and water activity in the product, to inhibit the growth of the microorganisms and prolonging the shelf life of the final product. One of most common drying methods is convective hot air drying. However, this method has many disadvantages such as lengthy drying time, darkening in color [2], the high temperature damaging the product quality and high power consumption [3]. The microwave drying provided an alternative way since it is an advantageous method due to its short drying time, ease of process control, power saving and drying homogenization. In fluidized bed dryer, the products in the granular structure are fluidized and excess moisture in the product structure is removed by a drying air. In addition, fluid bed drying process provides such as a good solids mix, high-speed heat-mass transfer and easy transport of substances advantages [4]. Therefore, fluid bed dryers are preferred due to their high heat transfer rates [5]. The drying industry utilizes large quantities of energy and for this reason one of the most important challenges of the drying industry is to reduce the power cost of obtaining good quality dried products. For this reason, drying operations can be applied intermittently in order not to damage the structure of the food, to adversely affect the quality and to save power [5].

The objective of this work is to investigate the effects of different drying processes (convective hot air, microwave, and fluidized bed drying) and combined drying methods on the drying characteristics and physical properties of parboiled wheat. In addition, the power consumption of the dryers was measured to use in the comparison.

\section{Materials and Methods}

\subsection{Material}

Wheat (Triticum aestivum) was supplied from a local market in İzmir/TURKEY. Wheat samples were soaked in the water (1:10 wheat:water ratio (weight:weight), (w:w)) at the room temperature $\left(25^{\circ} \mathrm{C}\right)$ overnight and was parboiled at $100^{\circ} \mathrm{C}$ for half an hour in the water (1:2 wheat:water ratio, (w:w)) and drained. The initial moisture content of the samples was $60.48 \pm 0.63 \%$.

\subsection{Methods}

\subsubsection{Drying Processes}

Pre-processed wheat samples were dried by using different drying methods and their combinations. The weight loss of the samples was measured by using an electronic balance 
(Ohaus AR2140, USA) until constant weight was reached. The drying conditions are given in the following Table 1.

Table 1. Drying methods and conditions

\begin{tabular}{|c|c|c|c|}
\hline Convective hot air drying & \multicolumn{2}{|c|}{ Fluidized bed drying } & Microwave drying \\
\hline $\begin{array}{l}\text { Armfield Lim., Ringwood, } \\
\text { Hampshire, UK }\end{array}$ & \multicolumn{2}{|c|}{ Sherwood Scientific, UK } & Arçelik MD595, Turkey \\
\hline $70^{\circ} \mathrm{C}$ and $1.6 \mathrm{~m} / \mathrm{s}$ air velocity & \multicolumn{2}{|c|}{$\begin{array}{c}60,70,80^{\circ} \mathrm{C} \text { and } 1.6 \mathrm{~m} / \mathrm{s} \text { air } \\
\text { velocity }\end{array}$} & $\begin{array}{c}180 \mathrm{~W}, 360 \mathrm{~W}, 540 \mathrm{~W}, 720 \mathrm{~W}, \\
\text { and } 900 \mathrm{~W}\end{array}$ \\
\hline $\begin{array}{l}\text { every } 5 \text { min. of weight } \\
\text { measurement }\end{array}$ & \multicolumn{2}{|c|}{$\begin{array}{c}\text { every } 5 \text { min. of weight } \\
\text { measurement }\end{array}$} & $\begin{array}{l}\text { every } 1 \text { min. of weight } \\
\text { measurement }\end{array}$ \\
\hline \multicolumn{2}{|c|}{ Intermittent fluidized bed-microwave drying } & \multicolumn{2}{|c|}{ Intermittent microwave- fluidized bed drying } \\
\hline \multicolumn{2}{|c|}{$\begin{array}{c}60-70-80^{\circ} \mathrm{C} \text { temperatures, } 1.6 \mathrm{~m} / \mathrm{s} \text { air flow for } 25 \\
\text { min }+ \text { microwave dryer }(180-360-540 \mathrm{~W})\end{array}$} & \multicolumn{2}{|c|}{$\begin{array}{l}180-360-540 \mathrm{~W} \text { for } 14 \mathrm{~min}+60-70-80^{\circ} \mathrm{C}, \\
1.6 \mathrm{~m} / \mathrm{s} \text { air flow }\end{array}$} \\
\hline
\end{tabular}

\subsubsection{Analysis}

The power consumptions of the dryers were measured by power measurement device (Makel M310.2218, Turkey). The moisture content of the dried wheat samples were determined according to AOAC (2000). The water activity and color ( $\mathrm{L}^{*}, \mathrm{a}^{*}$, and $\mathrm{b}^{*}$ ) values of the samples were measured by using a water activity measurement device (TestoAG 400, Germany) and a colorimeter (Minolta CR-400, Japan), respectively. The results were expressed in accordance with the CIE Lab. System and the Chroma and Hue Angle $\left(^{\circ}\right)$ values were calculated according to Maskan et al. (2000) [6].

\subsubsection{Determination of the drying behavior of the parboiled wheat samples}

The moisture content versus time and drying rate versus moisture content plots were prepared according to Maskan et al. (2000) [6].

\subsubsection{Statistical Analysis}

Data were analyzed using statistical software SPSS 16.0 (SPSS Inc., Chicago, IL, USA). The data were also subjected to analysis of variance (ANOVA) and Duncan's multiple range test $(\alpha=0.05)$ to determine the difference between means. The drying experiments were replicated twice and all analyses were triplicated.

\section{Results and Discussions}

The power consumption of the dryers, and the moisture content and water activity values of the dried wheat samples are given in Table 2. The highest power consumption value 
(18.63kWh) was observed for convective dryer because of long drying time (145min, data was not given). Considering the power consumption in the fluidized bed dryer (heating and blowing the air), the higher drying air temperatures caused a shorter drying time, and a shorter drying time caused significantly less power consumption $(\mathrm{P}<0.05)$. Toğrul $(2006)$ and Chen et al., (2001) [7,8] reported that the convective and fluidized drying methods have some disadvantages such as high power consumption due to long drying time. The lowest power consumption values were observed for microwave drying because of the low drying time (Figure 1). In addition, Alibas (2006) [9] reported that the microwave drying is a widely used method due to low drying time and power consumption. The power consumption significantly increased from 0.07 to $0.39 \mathrm{kWh}$ as microwave power increased from 180 to $900 \mathrm{~W}(\mathrm{P}<0.05)$ and the power values 720 and $900 \mathrm{~W}$ were eliminated from intermittent drying trials because of the higher power consumption and lower quality properties than other microwave drying powers. According to Table 1, it can be said that the power consumption of fluidized bed dryer can be decreased by combining it with microwave dryer and even the lower power consumption values were observed for fluidized bed-microwave combination compared to the microwave-fluidized bedcombination. Demiray et al. (2017) [10] reported that under convective drying conditions at the beginning of the drying the moisture removal rate is high, however, at the low moisture content values convective drying was not advantageous due to slow diffusion rate. For this reason, it can be stated that the fluidized bed-microwave combination is more advantageous with the higher evaporation rate, and lower power consumption compared to the microwave-fluidized bed-combination.

As can be seen from Table 1, the moisture content and water activity values of samples are generally lower than the limits ( $10 \%$ and in the range of 0.1 to 0.4 , respectively (Quek et al., (2007), [11], (except convective dried samples) indicating their microbial safety for long terms of storage. The moisture content and water activity values significantly affected by the drying techniques $(\mathrm{P}<0.05)$. Significantly higher moisture content values were observed for the samples which were dried at the convective dryer and fluidized bed dryer $(\mathrm{P}<0.05)$. The moisture content values of samples increased depending on the increase of the drying air temperature in the fluidized bed dryer might be due to the crust formation which prevents the removal of moisture. Microwave dried samples have the significantly lower moisture content values compared to convectively dried samples $(\mathrm{P}<0.05)$. The lowest water activity values were observed for the fluidized bed-microwave dried samples and the water activity values significantly decreased depending on the increasing drying air temperatures $(\mathrm{P}<0.05)$. The moisture content and water activity values for the fluidized bed-microwave dried samples were found to be significantly lower compared to the convectively and microwave-fluidized bed dried samples $(\mathrm{P}<0.05)$. 
Turkoglu, T.; Baykal, H.; Yuksel, H.; Caliskan Koc, G.; Dirim, S.N.

Table 2. The power consumption, moisture content, and water activity values of the dried wheat

\begin{tabular}{|c|c|c|c|c|}
\hline \multicolumn{2}{|c|}{ Drying methods and the conditions } & \multirow{2}{*}{$\begin{array}{c}\begin{array}{c}\text { Power Consumption } \\
\text { (kWh) }\end{array} \\
18.63 \pm 0.01^{\mathrm{f}}\end{array}$} & \multirow{2}{*}{$\begin{array}{c}\text { Moisture Content } \\
\text { (\% wet basis, wb) }\end{array}$} & \multirow{2}{*}{$\begin{array}{c}\text { Water } \\
\text { Activity } \\
0.45 \pm 0.00^{\mathrm{i}}\end{array}$} \\
\hline $\begin{array}{c}\text { Convective } \\
\text { Hot Air }\end{array}$ & $70^{\circ} \mathrm{C}, 1.6 \mathrm{~m} / \mathrm{s}$ & & & \\
\hline \multirow{3}{*}{ Fluidized Bed } & $60^{\circ} \mathrm{C}, 1.6 \mathrm{~m} / \mathrm{s}$ & $2.03 \pm 0.02^{\mathrm{e}}$ & $8.58 \pm 0.92^{\mathrm{c}}$ & $0.26 \pm 0.03^{f}$ \\
\hline & $70^{\circ} \mathrm{C}, 1.6 \mathrm{~m} / \mathrm{s}$ & $1.38 \pm 0.01^{\mathrm{cd}}$ & $8.59 \pm 0.74^{\mathrm{c}}$ & $0.25 \pm 0.01^{\mathrm{e}}$ \\
\hline & $80^{\circ} \mathrm{C}, 1.6 \mathrm{~m} / \mathrm{s}$ & $1.16 \pm 0.03^{c}$ & $10.80 \pm 0.54^{\mathrm{e}}$ & $0.22 \pm 0.01^{\mathrm{d}}$ \\
\hline \multirow{5}{*}{ Microwave } & $180 \mathrm{~W}$ & $0.07 \pm 0.01^{\mathrm{a}}$ & $1.53 \pm 0.32^{\mathrm{a}}$ & $0.20 \pm 0.02^{\mathrm{d}}$ \\
\hline & $360 \mathrm{~W}$ & $0.22 \pm 0.01^{\mathrm{a}}$ & $3.96 \pm 0.26^{\mathrm{b}}$ & $0.21 \pm 0.03^{\mathrm{d}}$ \\
\hline & $540 \mathrm{~W}$ & $0.29 \pm 0.02^{\mathrm{a}}$ & $2.05 \pm 0.28^{b}$ & $0.21 \pm 0.05^{\mathrm{d}}$ \\
\hline & 720W & $0.36 \pm 0.01^{b}$ & $1.21 \pm 0.10^{\mathrm{a}}$ & $0.31 \pm 0.02^{\mathrm{g}}$ \\
\hline & $900 \mathrm{~W}$ & $0.39 \pm 0.03^{b}$ & $1.68 \pm 0.18^{\mathrm{a}}$ & $0.36 \pm 0.04^{f}$ \\
\hline \multirow{3}{*}{$\begin{array}{c}\text { Microwave- } \\
\text { Fluidized Bed }\end{array}$} & $180 \mathrm{~W}-60^{\circ} \mathrm{C}, 1.6 \mathrm{~m} / \mathrm{s}$ & $1.60 \pm 0.02^{\mathrm{cd}}$ & $8.04 \pm 0.91^{d}$ & $0.24 \pm 0.01^{\mathrm{e}}$ \\
\hline & $360 \mathrm{~W}-60^{\circ} \mathrm{C}, 1.6 \mathrm{~m} / \mathrm{s}$ & $1.26 \pm 0.01^{\mathrm{cd}}$ & $8.26 \pm 0.22^{\mathrm{a}}$ & $0.31 \pm 0.02^{g}$ \\
\hline & $540 \mathrm{~W}-60^{\circ} \mathrm{C}, 1.6 \mathrm{~m} / \mathrm{s}$ & $0.91 \pm 0.02$ & $6.23 \pm 0.46^{\mathrm{a}}$ & $0.43 \pm 0.01^{\mathrm{h}}$ \\
\hline \multirow{2}{*}{$\begin{array}{l}\text { Fluidized } \\
\text { Bed- }\end{array}$} & $60^{\circ} \mathrm{C}-180 \mathrm{~W} 1.6 \mathrm{~m} / \mathrm{s}$ & $0.77 \pm 0.01^{\text {bc }}$ & $3.81 \pm 0.34^{\mathrm{b}}$ & $0.10 \pm 0.02^{\mathrm{c}}$ \\
\hline & $60^{\circ} \mathrm{C}-360 \mathrm{~W}, 1.6 \mathrm{~m} / \mathrm{s}$ & $0.88 \pm 0.01^{\mathrm{bc}}$ & $1.18 \pm 0.25^{\mathrm{a}}$ & $0.06 \pm 0.04^{\mathrm{a}}$ \\
\hline Microwave & $60^{\circ} \mathrm{C}-540 \mathrm{~W}, 1.6 \mathrm{~m} / \mathrm{s}$ & $0.94 \pm 0.01^{\mathrm{c}}$ & $1.09 \pm 0.29^{\mathrm{a}}$ & $0.08 \pm 0.02^{\mathrm{b}}$ \\
\hline
\end{tabular}

a- I show the significant difference between the same column in the samples according to the moisture content, water activity, and power consumption $(\mathrm{P}<0.05)$.

The total color change, Hue angle, and chroma values of the samples are given in Table 3. The $L^{*}, a^{*}$ and $b^{*}$ values of the parboiled wheat are measured $63.43 \pm 0.63,-0.57 \pm 0.38$ and $15.13 \pm 0.12$ respectively. The total color change $(\Delta \mathrm{E})$ of dried samples with respect to parboiled wheat was calculated and the significantly higher total color change values were observed for microwave dried samples $(\mathrm{P}<0.05)$. It was clearly seen that the total color change was dramatically decreased in the intermittent drying methods especially in the fluidized bed- microwave drying method. The color change may be due to the degradation of the pigments, browning reactions or burning. The higher hue angle values were measured for microwave dried samples indicating higher redness values in this drying method. The chroma value indicates the degree of saturation of color and is proportional to the strength of the color [6]. The lowest chroma values were observed for fluidized bedmicrowave dried wheat samples.

The drying rates were calculated and plotted against the moisture content as shown in Fig. 1. The drying generally occurred in falling rate period in the all drying methods due to the high evaporation rate of moisture. 
Table 3. The total color change, hue angle and chroma values of the dried wheat

\begin{tabular}{|c|c|c|c|c|}
\hline \multirow{2}{*}{\multicolumn{2}{|c|}{ Drying method and the condition }} & \multicolumn{3}{|c|}{ Colour } \\
\hline & & \multirow{2}{*}{$\begin{array}{c}\Delta \mathbf{E} \\
7.58 \pm 0.51^{\mathrm{a}}\end{array}$} & \multirow{2}{*}{\begin{tabular}{|c|} 
Hue Angle \\
$1.51 \pm 0.00^{\mathrm{d}}$
\end{tabular}} & \multirow{2}{*}{$\begin{array}{c}\text { Chroma } \\
21.67 \pm 0.57^{\mathrm{ab}}\end{array}$} \\
\hline $\begin{array}{c}\text { Convective Hot } \\
\text { Air }\end{array}$ & $70^{\circ} \mathrm{C}, 1.6 \mathrm{~m} / \mathrm{s}$ & & & \\
\hline \multirow{3}{*}{ Fluidized Bed } & $60^{\circ} \mathrm{C}, 1.6 \mathrm{~m} / \mathrm{s}$ & $10.86 \pm 0.29^{\mathrm{bcd}}$ & $1.49 \pm 0.0^{\mathrm{ab}}$ & $20.13 \pm 0.39^{\mathrm{ab}}$ \\
\hline & $70^{\circ} \mathrm{C}, 1.6 \mathrm{~m} / \mathrm{s}$ & $16.88 \pm 0.26^{\mathrm{d}}$ & $1.38 \pm 0.01^{\mathrm{ab}}$ & $25.35 \pm 0.39^{\mathrm{ab}}$ \\
\hline & $80^{\circ} \mathrm{C}, 1.6 \mathrm{~m} / \mathrm{s}$ & $10.78 \pm 0.03^{c}$ & $1.49 \pm 0.01^{\mathrm{a}}$ & $21.49 \pm 0.40^{\mathrm{ab}}$ \\
\hline \multirow{5}{*}{ Microwave } & $180 \mathrm{~W}$ & $35.24 \pm 2.75^{\mathrm{a}}$ & $1.15 \pm 0.06^{\mathrm{d}}$ & $19.96 \pm 3.46^{\mathrm{ab}}$ \\
\hline & $360 \mathrm{~W}$ & $30.12 \pm 1.09^{\mathrm{bcd}}$ & $1.16 \pm 0.02^{\mathrm{bc}}$ & $24.05 \pm 0.90^{\mathrm{ab}}$ \\
\hline & $540 \mathrm{~W}$ & $30.03 \pm 0.50^{\mathrm{d}}$ & $1.07 \pm 0.01^{\mathrm{abc}}$ & $20.25 \pm 0.70^{\mathrm{ab}}$ \\
\hline & 720W & $29.81 \pm 0.63^{\mathrm{bcd}}$ & $1.15 \pm 0.02^{\mathrm{ab}}$ & $21.55 \pm 0.25^{b}$ \\
\hline & $900 \mathrm{~W}$ & $33.80 \pm 0.50^{\mathrm{bcd}}$ & $1.15 \pm 0.01^{\mathrm{ab}}$ & $22.80 \pm 0.67^{\mathrm{ab}}$ \\
\hline \multirow{3}{*}{$\begin{array}{l}\text { Microwave- } \\
\text { Fluidized Bed }\end{array}$} & $180 \mathrm{~W}-60^{\circ} \mathrm{C}$ & $11.37 \pm 1.09^{\text {bcd }}$ & $1.51 \pm 0.03^{\mathrm{bc}}$ & $21.00 \pm 3.44^{\mathrm{b}}$ \\
\hline & $360 \mathrm{~W}-60^{\circ} \mathrm{C}$ & $15.05 \pm 0.87^{\mathrm{ab}}$ & $1.45 \pm 0.02^{\mathrm{ac}}$ & $25.54 \pm 0.80^{\mathrm{ab}}$ \\
\hline & $540 \mathrm{~W}-60^{\circ} \mathrm{C}$ & $13.17 \pm 2.23^{\mathrm{d}}$ & $1.46 \pm 0.03^{\mathrm{ab}}$ & $21.13 \pm 2.08^{\mathrm{a}}$ \\
\hline \multirow{3}{*}{$\begin{array}{l}\text { Fluidized Bed- } \\
\text { Microwave }\end{array}$} & $60^{\circ} \mathrm{C}-180 \mathrm{~W}$ & $6.25 \pm 3.75^{\mathrm{d}}$ & $0.51 \pm 1.47^{\mathrm{ab}}$ & $16.56 \pm 2.75^{\mathrm{ab}}$ \\
\hline & $60^{\circ} \mathrm{C}-360 \mathrm{~W}$ & $6.79 \pm 1.47^{\mathrm{cd}}$ & $1.53 \pm 0.02^{\mathrm{abc}}$ & $18.18 \pm 2.4^{\mathrm{ab}}$ \\
\hline & $60^{\circ} \mathrm{C}-540 \mathrm{~W}$ & $8.98 \pm 1.96^{\mathrm{ab}}$ & $1.47 \pm 0.02^{\mathrm{cd}}$ & $22.81 \pm 1.99^{\mathrm{ab}}$ \\
\hline
\end{tabular}

Since almost all of the drying of biological products take place in the falling rate period [6] the drying rate of samples increased depending on increasing in drying air temperature and/or microwave power and the required drying time and the power consumption generally significantly decreased $(\mathrm{P}<0.05)$. In the all drying techniques, initially higher drying rates were observed and the samples tended to dry slowly at the last stages of drying.

It may be due to shrinkage or crust formation resulting in low transport rate of water and prolonged drying time. The highest drying rate values were observed for the microwave dried wheat grains where the lowest values were observed for the fluidized bed-microwave dried samples. The microwave drying supplies a higher drying rate compared to convective drying methods because of the heat generation inside food material which causes a rapid moisture evaporation in microwave drying [12].

The drying characteristics of wheat samples during drying were determined from the mass loss in the samples of the known initial moisture content $(66.48 \pm 0.63 \%$, wb) and are given in Figure 2. as expected, high amounts of moisture were removed at the early stages of drying due to the higher moisture diffusion and at the later stages, the removal of moisture decreased gradually. 
(a)

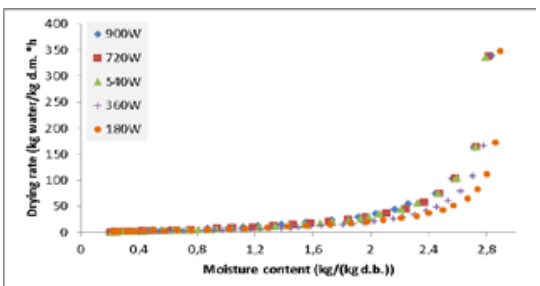

(c)

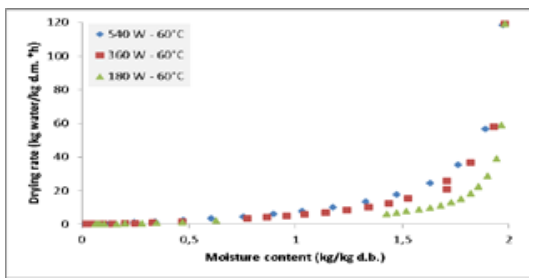

(b)

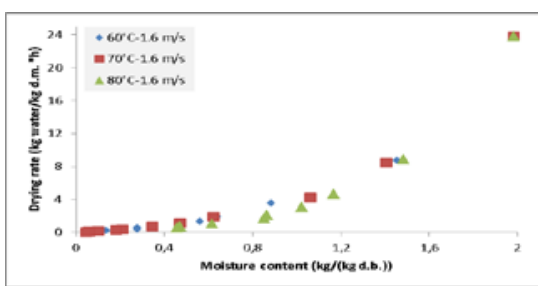

(d)

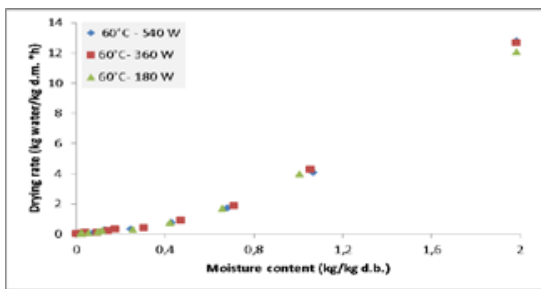

Fig. 1 The drying rate versus moisture content for (a)Microwave drying, (b)Fluidized bed drying (c) Microwave-fluidized bed combination, (d) Fluidized bed-microwave drying combination.

As expected, drying time of samples decreased with increasing microwave power and/or drying air temperature. Drying behavior of the wheat samples showed similar trend for the all the drying methods.

(a)

(c)
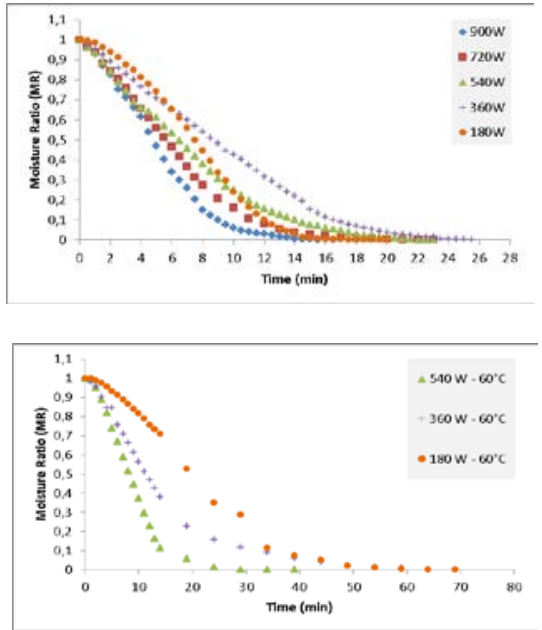

(b)
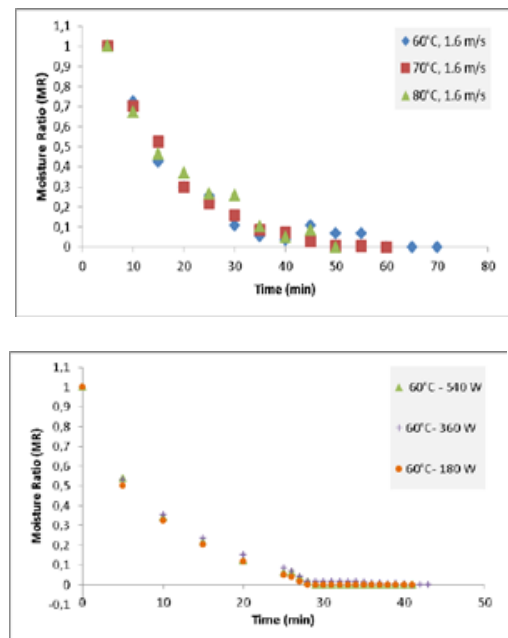

(d)

Fig. 2 The drying Characteristics for (a) Microwave drying, (b) Fluidized bed drying (c) Microwave-fluidized bed combination, (d) Fluidized bed-microwave drying combination. 


\section{Conclusions}

In this study, the drying characteristics (moisture ratio vs. time graphs) and the physical analysis (moisture content, water activity, and color determination) of the single dried and combined dried wheat samples were determined. The power consumption for each drying method was also evaluated. Although, the lowest power consumption $(0.07 \mathrm{kWh})$ was observed for $180 \mathrm{~W}$ microwave drying condition, considering the quality of the dried wheat especially the highest total color change was determined by this drying condition. The lowest moisture content (1.09\%) and the water activity $(0.06)$ values were observed at $60^{\circ} \mathrm{C}$ $540 \mathrm{~W}$ fluidized bed-microwave dried and $60^{\circ} \mathrm{C}-360 \mathrm{~W}$ fluidized bed- microwave dried wheat. The lowest total color change values were observed in fluidized bed-microwave dried wheat samples in the range between 6.28-8.98. The results showed that the fluidized bed-microwave drying methods were better for the physical properties and the low power consumption when they are compared to the microwave-fluidized bed combinations.

\section{References}

[1] Mohapatra, D.; Rao, P.S. A thin layer drying model of parboiled wheat. Journal of Food Engineering 2005, 513-518.

[2] Politowicz, J.; Lech, K.; Sanchez-Rodríguez, L.; Figiel, A., Szumny, A., Grubor, M., Barrachina, A. Volatile composition and sensory profile of oyster mushroom as affected by drying method. Drying Technology 2017.

[3] Kotwaliwale, N.; Bakane, P.; Verma, A. Changes in textural and optical properties of oyster mushroom during hot air drying. Journal of Food Engineering 2007, 78, 1207-1211.

[4] Mujumdar, A.S. Handbook of Industrial Drying, Third Edition, Taylor \& Francis Group, LLC, 2006.

[5] Milota, M. R. Engineering Study on the Drying of Wood Particles in a Fluidized Bed, A Thesis Submitted to Oregon State University, 1984. USA.

[6] Maskan M.Microwave/air and microwave finish drying of banana Journal of Food Engineering 2000, (44) 71-78.

[7]Toğrul, H. Suitable drying model for infrared drying of carrot, Journal of Food Engineering 2006, 77: 610-619.

[8] Chen, G.; Wang, W.; Mujumdar, A.S. Theoretical study of microwave heating patterns on batch fluidized bed drying of porous material, Chemical Engineering Science 2001, 56, 6823-6835.

[9] Alibas, I. Characteristics of chard leaves during microwave, convective, and combined microwave convective drying. Drying Technology 2006, 24(1):1425- 1435.

[10] Demiray, E.; Seker, A.; Tulek, Y.; Drying kinetics of onion (Allium cepa L.) slices with convective and microwave drying Heat and Mass Transfer, 2017, 53, (5)1817-1827.

[11] Quek, S.Y.; C, N.K. ; S, P.J. The physicochemical Properties of Spray Dried Watermelon Powders, Chemical Engineering and Processing 2007, 46 (5), 386-392.

[12] Reyes, A.; Cero_n, S.; Zu_n iga, R.; Moyano, P.A comparative study of microwave-assisted airdrying of potato slices. Biosystem Engineering 2007, 98, 310-318. 